\title{
The Influence of Pandemic Covid-19 on Small Business Enterprise in West Nusa Tenggara Province
}

\author{
Rosiady Husaenie Sayuti* \\ Department of Sociology \\ University of Mataram \\ Mataram, Indonesia \\ sayuti@unram.ac.id
}

\author{
Siti Aisyah Hidayat \\ Faculty of Economics and Business University \\ University of Mataram \\ Mataram, Indonesia \\ sayuti@unram.ac.id
}

\begin{abstract}
The arrival of the Covid-19 Pandemic was never imagined at all. Moreover, then this pandemic swept across the world. There is almost no country that is not affected by this pandemic. The first patient announced by the President of the Republic of Indonesia, Joko Widodo, came from Depok, on March 2, 2020. Since that day, positive cases of Covid-19 have caught the attention of all Indonesians, because the number continues to grow rapidly from day to day. One of the groups of people affected by this pandemic is Micro and Small Business Enterprises (MSBEs). Automatically, when people's activities outside the home are limited, their need for various MSBE products will decrease. As a result, the life and contribution of MSBEs to the community's economy are also affected. This research was conducted using descriptive methods. Data collection was carried out by distributing questionnaires in google form format, through various MSBE communities in NTB. The research objectives were (1) to determine how far the impact felt by MSBEs as a result of this pandemic; (2) to find out whether there are benefits felt by MSBE actors when they become members of an association (association) based on MSBEs. The impacts they experience are related to income, the imposition of layoffs, and changes in production models or systems. The results of this study indicate that in general most of the MSBEs are affected by this pandemic; In addition, the involvement of MSBEs in associations has an influence on their business performance. Therefore, it is suggested that in this pandemic situation the government can play a more active role, so that the performance of MSBEs can continue to grow and contribute to the economic growth of the community.
\end{abstract}

Keywords-MSMEs, Small Business Enterprise, Pandemic Covid-19, Economic Growth

\section{INTRODUCTION}

The massive and uncontrolled spread of the Covid-19 virus in various parts of the world has made the WHO (World Health Organization) officially announce that Covid-19 has been a world pandemic since March 11, 2020. The pandemic was announced not only as a medical need preparedness, but preparedness for various aspects will be affected, both in the social, cultural and economic fields. This is as projected by the International Monetary Fund (IMF) that the global economy grows at minus $3 \%$. This condition is reflected in the first quarter after the existence of Covid-19 shows that economic growth in a number of Indonesia's trading partners grew negatively, with details of Singapore -2.2, Hong Kong -8.9, European Union -2.7 , and China experiencing a decline of up to $-6.8[1],[2]$.
The reality of economic growth that occurs in Indonesia's trading partners also has implications for Indonesia's economic growth. In the first quarter, Indonesia's economic growth only reached $4.9 \%$ and the second quarter contracted $5.32 \%$ and for the third quarter the Minister of Finance has confirmed Indonesia's economic growth will be in the range of $-2.9 \%$ and $-1 \%$ [3], [4]. The condition of Indonesia's economic growth is influenced by the existence of social distancing policies and the issuance of PP Number 21 of 2020 concerning Large-Scale Social Restrictions which aims to limit the movement of large numbers of people and limit the movement of goods and requires people to stay at home if they do not have urgent interests [5], [6]. This policy certainly limits the operational activities carried out by MSME players compared to previous days.

Indonesia's economic growth is supported by the existence of MSMEs as the main pillars of the national economy. This is as data obtained from the Ministry of Cooperatives and Small and Medium Enterprises shows that in 2018 Indonesia there were 64,194,057 MSMEs and employing 116,978,631 workers [4], [5]. The growth in the number of MSME units in the last three years from 2016 - 2019 has increased by 4.25 percent annually and the average contribution of MSMEs to Indonesia's Gross Domestic Product (GDP) over the last 3 years is more than 50 percent (Noer, 2020). However, the existence of the Covid-19 pandemic has seriously affected MSMEs, not only in terms of production and income, but also has an impact on the number of workers that must be reduced. This is also reinforced by data released by the organization for Economic Co-operation and Development (OECD), which states that MSMEs have been significantly affected by the presence of Covid 19. MSMEs are very vulnerable to being affected by business disruption, because they often have direct contact with tourism, transportation and the culinary industry which requires fast suppliers, all of which have been significantly affected by covid-19 [7].

In fact, MSMEs are considered capable of surviving after the economic crisis in Indonesia in 1997. Over time, the development of MSMEs has grown rapidly and is in demand by various groups. This proves that MSMEs have the ability to survive with their businesses amid the economic crisis that occurs compared to large-scale companies. This means that the growth of MSMEs is also considered as one of the driving factors for an economy that is being hit by a crisis. However, in the midst of the Covid-19 pandemic, such as the results of a BPS survey which reported that in general, 8 out of every 10 
companies, both MSEs and UMB, tended to experience a decline in demand. Meanwhile, 6 out of every 10 UMK and UMB companies also face obstacles due to badly affected business partners or unable to operate [8]. This means that the current crisis due to the Covid-19 pandemic is different from the crisis that occurred previously. So that it takes real efforts to overcome the problems experienced by MSME players.

One of the areas affected by the Covid-19 pandemic is the Province of NTB, where with the increasing outbreak of this virus since early March 2020, one by one shops, retail, tourism services, MSMEs / IKM in NTB closed their operations and caused many employees to be laid off due to decreased income. drastically obtained due to decreased purchasing power of the community. As data revealed by Nuryanti as Head of the NTB Industry Service, the small and medium industries (IKM) affected by the Covid-19 pandemic reached 5,000 units, including MSMEs and this data is still moving [9].

Meanwhile, the trade sector in NTB is one of the sectors with the largest number of businesses and workers in NTB, so its sustainability is highly dependent on mobility activities carried out, both the mobility of goods distribution and the mobility of business actors. In fact, MSMEs (Micro, Small and Medium Enterprises) are one of the business fields that have an important role for economic growth in NTB. In addition, MSMEs have a share in the absorption of labor and distribution of development results [1], [10]. In line with that, this study wants to find out the factors that influence the increase or decrease in income during the Covid-19 pandemic for MSME players who partner with the government or MSME associations in NTB.

Based on the description above, the research was carried out with the following objectives: (1) To what extent has the Covid-19 pandemic affected the performance of MSMEs in NTB, especially in relation to income, the imposition of layoffs, and changes in the production process for each UMKM, and (2) What is the role of the UMKM Association in helping the MSMEs involved in the association during this pandemic.

\section{METHODS}

The type of research used in this study is a behavioral survey of MSME actors during the Covid-19 Pandemic. Using the Non Probability Sampling design with a combination of Voluntary and Snowball Sampling to get as much participatory response as possible from 8 July to 19 July 2020. Data collection was carried out using an online questioner with the help of a google form which was distributed using WhatsApp Group media for MSME players in NTB . The following describes the characteristics of the respondents who were the samples in this study.

\section{RESULTS DAN DISCUSSION}

\section{A. Characteristics of Respondents}

TABLE I. CHARACTERISTICS OF RESPONDENTS

\begin{tabular}{|c|c|c|c|c|c|c|c|c|}
\hline Information & T.S & SD & SLTP & SLTA & Diploma & Bachelor & Postgraduate & Total \\
\hline Last Education & $1 \%$ & $2 \%$ & $5 \%$ & $32 \%$ & $10 \%$ & $47 \%$ & $3 \%$ & $100 \%$ \\
\hline \multirow{2}{*}{\multicolumn{2}{|c|}{ Gender }} & \multicolumn{2}{|c|}{ Male } & $\%$ & \multicolumn{2}{|c|}{ Female } & $\%$ & Total \\
\hline & & \multicolumn{2}{|c|}{78} & $78 \%$ & \multicolumn{2}{|c|}{22} & $22 \%$ & $100 \%$ \\
\hline \multirow{2}{*}{\multicolumn{2}{|c|}{ Business Location }} & & illages & $\%$ & \multicolumn{2}{|c|}{ Cities } & $\%$ & Total \\
\hline & & & 40 & 40 & \multicolumn{2}{|c|}{60} & 60 & $100 \%$ \\
\hline \multicolumn{2}{|l|}{ MSME Associations } & & Yes & $\%$ & \multicolumn{2}{|c|}{ No } & $\%$ & Total \\
\hline & & & 57 & 57 & \multicolumn{2}{|c|}{43} & 43 & $100 \%$ \\
\hline
\end{tabular}

Source: compiled from survey results

Characteristics of respondents seen from the last education level of MSME actors in NTB from 100 respondents, the last education level of respondents who did not attend school (TS) was $1 \%$, SD was $2 \%$, SLTP was $5 \%$, SLTA $32 \%$, Bachelor $47 \%$, and Postgraduate $3 \%$. Referring to the answers of 100 respondents as NTB MSME actors who have entered and been verified, initial information is obtained about the characteristics of respondents seen from the gender indicator: $78 \%$ of respondents are male and $22 \%$ of respondents are female. Based on the table above, if examined from the survey results that have been carried out using the business location indicator, it shows that the MSMEs in NTB who became respondents consisted of $40 \%$ of business locations in villages and $60 \%$ of respondents' MSMEs domiciled in cities. Based on the data above, it can be seen that of the 100 respondents who have answered the questionnaire, there are 57 respondents who are members of or involved in the MSME Association and 43 respondents who are not members of the UMKM Association.
This survey certainly has advantages and disadvantages because it is conducted online. The advantages of this survey are (1) Providing up-to-date statistical data which is analyzed so that it is able to respond to data needs quickly. (2) As a tool to provide an overview and current conditions regarding the impact experienced by MSME actors in NTB Province. (3) The questions in the questionnaire are designed to fulfill information needs regarding the impacts and efforts that can be given to MSME actors. While the limitations of this survey are (1) The resulting analysis is a description of individuals who have voluntarily participated in filling out the survey questionnaire. (2) Not being able to reach MSME players who do not have digital access.

\section{B. Condition of NTB MSMEs During the Pandemic Covid- 19}

Since the notification of the first case of NTB residents who were confirmed positive for Covid-19 on March 24, 2020 , since then the public has been urged to be vigilant and 
carry out social distancing to prevent the addition of new cases. The existence of this policy makes community activities change to do everything at home, both for school and work activities [4]. This was carried out considering that cases of Covid-19 infection continued to increase, and there were even three areas namely Mataram, East Lombok and Sumbawa in April which were in the red zone.

On the other hand, this policy indirectly affects the economy of MSME players in NTB. This is because they cannot carry out their operational activities like normal days. So, it is not surprising that during the Covid-19 pandemic, MSME players in NTB whose businesses experienced changes in income, enforced layoffs and changed the production system. However, the NTB Provincial Government does not remain silent in facing this condition. Various efforts were made to ease the burden on MSME players who were affected by the Covid-19 Pandemic and restore the community's economy. Together with stakeholders related to the government, they continue to strive to strengthen local MSMEs. This strengthening is not only in terms of human resources by equipping them with various types of skills training. But it also continues to improve entrepreneurial skills, improve product quality and expand competitiveness and market access.

Various trainings that have been held include co-operative training in tourism areas, business management training for community market cooperatives, KSP / KPPS cooperative compliance training, participation of the business world in apprenticeship activities for youth, vocational training in postdisaster areas, training in home decor entrepreneurship, Fashion entrepreneurship training, vocational training for plantation communities, competency-based LKM management training, and creative economy-based entrepreneurship training [11].

In addition, the NTB provincial government also conducts empowerment through the JPS Gemilang program. The program, which is intended to help meet the needs of the community and empower the local economy, contains local MSME products in the form of a basic food package and a mask plus supplement package which contains $10 \mathrm{~kg}$ of rice,
20 eggs, 1 liter of cooking oil, processed fish products in this case shredded fish. , 3 Non-Medical Masks, 100 gr Soy Milk / Ginger Powder, Liquid Soap / Stems, Eucalyptus Oil and Moringa Leaf Tea (kkp.go.id, accessed 12/15/2020). Through the various efforts that have been made by the NTB Provincial Government, of course, the hope is that it will be able to boost the economy of the community which had collapsed, especially for MSME players.

As for more details regarding the current condition of MSMEs in NTB, the researchers will describe it as follows:

\section{Changes in Income During the Pandemic Covid-19}

Changes in business income experienced by MSME business actors in NTB are also something that cannot be avoided during the Covid-19 pandemic considering that they cannot carry out their business operations like the previous days. Therefore, data regarding changes in the income of NTB MSMEs during the Covid-19 pandemic are presented and processed by researchers from the results of data collection through goggle form media in the following image.

TABLE II. THE COVID-19 PANDEMIC AFFECTS BusinesS INCOME

\begin{tabular}{|ll|c|c|c|c|c|}
\hline \multicolumn{1}{|c|}{ Information } & Yes & \% & No & \% & Total \\
\hline $\begin{array}{l}\text { Pandemic-Covid-19 Affects } \\
\text { Business Income }\end{array}$ & 89 & $89 \%$ & 11 & $11 \%$ & $100 \%$ \\
\hline
\end{tabular}

Source: compiled from survey results

Looking at respondents' answers to the question "does the Covid-19 pandemic affect business income you?", it is known that from 100 respondents, 89\% of respondents whose business has changed during the Covid-19 pandemic and only $11 \%$ of respondents whose business is not affected by the existence of the Covid-19 pandemic. In other words, from these data it can be said that most MSMEs in NTB during the Covid-19 pandemic had an impact on changes in income. Furthermore, to see in more detail the changes in income experienced by MSME actors in NTB, whether it has increased or decreased, can be seen in the following table data.

TABLE III. Changes IN INCOME DuRING THE COVID-19 PANDEMIC

\begin{tabular}{|c|c|c|c|c|c|c|}
\hline Information & Increase & $\%$ & Descrease & \% & No Answer & Total \\
\hline $\begin{array}{c}\text { Change in Income During the } \\
\text { Pandemic }\end{array}$ & 25 & $25 \%$ & 64 & $64 \%$ & 11 \\
\hline
\end{tabular}

Source: processed from survey results

Based on the data above in general it can be said that changes in MSME income in NTB, it shows that $64 \%$ of respondents whose business income has decreased during the Covid-19 pandemic. Meanwhile, $25 \%$ of respondents whose business income experienced an increase in income and $11 \%$ of respondents did not answer because their business had not experienced a change in income during the Covid-19 pandemic. This means that the income of NTB MSMEs during the Covid-19 pandemic has significantly decreased compared to the increase in business income. This means that even though most of the MSME players have experienced a decrease in income, some MSMEs can still survive, even as many as $25 \%$ of respondents said their income had increased. As stated by Pratiwi, so far, MSMEs have proven their ability to survive in difficult economic situations. Most of the MSMEs have not had direct contact with the domestic financial sector, let alone global [12]. This situation has caused MSMEs to be able to withstand the global financial crisis such as in 1998.

The factors that led to a decrease in income obtained from filling out questionnaires via google form which are set in the form of open questions include a) low consumer interest in shopping, b ) raw materials that are difficult to obtain as a result of the PSBB policy because many NTB MSMEs are supplying raw materials from outside the region, c) constraints in the application of technology and the number of decreasing demands. Decreased income even hundreds of MSMEs have 
closed their businesses after the government officially announced that people work from home, close public services, and require people to wear masks and do social activities. Distancing . Even in mid-May in East Java, the PSBB (LargeScale Social Restriction) was implemented along with fines and criminal sanctions such as in the Surabaya, Sidoarjo and Gersik areas, making several areas that have been the lifeblood of trade in East Java have to close.

The economy of West Nusa Tenggara Province during the Covid-19 pandemic was still in a stagnant condition. This is because the wheels of the economy, both national and regional, are still in a state of uncertainty due to the threat of a recession which has weakened people's purchasing power [1], [4]. NTB Province is also one of the provinces that recorded negative growth at minus 1.41 percent. However, the economic condition of NTB is still better when compared to Bali Province and East Nusa Tenggara Province [9].

Furthermore, from data related to changes in income experienced by NTB MSME players during the Covid-19 pandemic, detailed data is presented to see the role of the MSME association which is described in the following data table presentation.

\section{Income Relationship with Association Membership During the Pandemic}

TABLE IV. INCOMES OF MSME ASSOCIATIONS DURING THE COVID-19 PANDEMIC

\begin{tabular}{ccccccc}
\hline Description & Unchanged & \% & Increase & \% & Decrease & Total \\
\hline MSME Associations & 5 & $8,8 \%$ & 14 & $24,6 \%$ & 38 & $66,7 \%$ \\
Non-MSME Associations & 6 & $14 \%$ & 11 & $25,6 \%$ & 26 \\
Total & 11 & & 25 & $60,5 \%$ & 64 & \\
\hline
\end{tabular}

Source: processed from the survey results

Judging from the table of changes in income between associated and unassociated MSMEs, that for respondents who joined the MSME Association, totaling 57 respondents, data was obtained $8.8 \%$ of respondents who did not experience a change in income, $24.6 \%$ of business respondents experienced an increase, and for respondents who experienced a decrease in income during the Covid-19 pandemic amounted to $66.7 \%$. Meanwhile, from a total of 43 respondents who did not join the UMKM association, it can be seen that $14 \%$ of respondents experienced changes in income during the Covid-19 pandemic, $25.6 \%$ of respondents experienced an increase in income and $60.5 \%$ of respondents experienced a decrease in business income. This means that both respondents who are members of the MSME association and those who are not part of the UMKM association during the Covid-19 pandemic have seen a significant decrease in business income.

\section{Layoffs During the Pandemic Covid-19}

Layoffs (Termination of Employment) became a very unsettling matter for workers, especially for workers. This is because the impact caused by layoffs can eliminate workers' income to meet their daily needs and also their families. So that the application of layoffs should not be carried out arbitrarily by a company or entrepreneur, including those classified as MSMEs. The government also protects workers by issuing Articles 150 to Article 151 which contain provisions for dismissal that must be followed (Putri, 2020). However, if a decision to continue layoffs is due to certain conditions that make the company or employer forced to lay off the employees, this must also be negotiated with the worker or laborer. The imposition of layoffs is something that cannot be avoided by hundreds of companies or entrepreneurs in Indonesia during the Covid-19 pandemic because many business activities have been hampered or even stopped. This is what happened in NTB, the imposition of layoffs for workers is something that cannot be avoided, both for those who partner with the government and those who are not partners. As for more details, the data on the enforcement of layoffs by MSMEs that are incorporated into Government
Partners and MSMEs who are members of the UMKM Association are described in the following table:

TABLE V. MSMES (ASSOCIATIONS) WHO DID LAYOFFS DURING THE PANDEMIC COVID-19

\begin{tabular}{cccccc}
\hline Information & Yes & \% & No & \% & Total \\
\hline UMKM Associations & 19 & $33,3 \%$ & 38 & $66,7 \%$ & $100 \%$ \\
Non-MSME Association & 7 & $16,3 \%$ & 36 & $83,7 \%$ & $100 \%$ \\
Total & 26 & & 74 & & \\
\hline
\end{tabular}

Source: processed from Survey results

Table $\mathrm{V}$ presents data from the MSME group involved in the association with those not involved in the UMKM association which is related to their performance in terms of layoffs. From the table above, it can be seen that of the total 57 respondents who joined the MSME association, 33.3\% did layoffs of their employees and $66.7 \%$ did not lay off employees. Furthermore, from a total of 43 respondents who did not join the UMKM association, it was shown that a percentage of $16.3 \%$ made policies for employee layoffs and $83.7 \%$ did not enforce layoffs of their employees. Therefore, from the data in the table, it can be concluded that both MSMEs who are members of the UMKM and UMKM associations are not members of the UMKM association, mostly, about two-thirds of whom did not lay off their employees during this pandemic. This shows that their level of resilience in facing the dynamics of the business world during the pandemic is relatively high.

\section{Changes in Production Systems During the Covid-19 Pandemic}

The business production system is an integral part of the running process of MSME business operations because at this stage the process is passed to produce the output of a business. Each UMKM has a different production system depending on the type of business it has. The existence of the Covid-19 pandemic directly affects the changes in the production system carried out by NTB MSME business actors. Changes in the system, the production includes changing the 
conventional work system to employees working online at their respective homes, or employees continuing to work by reducing working hours, or employees continuing to work as usual by complying with health protocols. However, there are also MSME business actors whose production systems have not changed. This means that they continue to employ their employees as usual. For more details, it will be described as follows.

TABLE VI. Changes IN PRoduction Systems During THE PANDEMIC

\begin{tabular}{cccccc}
\hline Information & Yes & $\%$ & No & \% & Total \\
\hline UMKM Associations & 44 & $77,2 \%$ & 13 & $22,8 \%$ & $100 \%$ \\
Non-MSME Association & 15 & $34,9 \%$ & 28 & $65,1 \%$ & $100 \%$ \\
Total & 59 & & 41 & & \\
\hline
\end{tabular}

Source: processed from Survey results

Table VI above shows that $77.2 \%$ of the total respondents who joined the MSME Association, decided to make changes to their business production systems and $22.8 \%$ of respondents did not make changes to his business production system during this covid-19 pandemic. Meanwhile, when viewed from a total of 43 respondents who were not part of the UMKM association, it shows that $34.9 \%$ made changes to the production system and $65.1 \%$ of respondents did not make changes to the business production system during the Covid19 pandemic. It can be seen that proportionally the MSMEs involved in associations have more tendency to change in their production systems as described above. On the other hand, MSMEs who are not involved in the association, most of them have not changed in their production system. This data shows the influence of the involvement of MSMEs in an association on the performance of the production process and their business activities.

Based on the findings of the data presented above related to the condition of NTB MSMEs in relation to being involved or not being involved in an MSME association during the Covid-19 pandemic, it can be analyzed into three things, namely dynamics related to business income, enforcement Layoffs of employees, and changes in production systems made to maintain business activities.

First, the phenomenon that describes MSMEs that are members of the UMKM and UMKM associations that are not part of the MSME association during the Covid-19 pandemic can be studied using James Coleman's framework of thinking regarding social capital. Coleman, through his major work entitled "Foundation of Social Theory" states that social capital is the same as economic capital which is productive or can bring benefits in certain situations [13]. The relationship or closeness that exists between MSME actors and the government as a social structure engaged in the empowerment of NTB MSMEs, Coleman believes, can bring benefits and can facilitate access to more extensive information acquisition by NTB MSME players in the fields of production to product marketing.

However, Coleman also said that in certain situations, social capital also cannot function or can not bring benefits to actors in a social structure. This theory can explain the benefits that can be obtained by associated MSMEs, compared to unassociated MSMEs. The closeness between MSMEs and policy makers who create a network between the two, does not necessarily result in better economic performance. During the Covid-19 pandemic, most MSMEs experienced a decline in operating income (Table IV). This can be understood because with the existence of social restrictions and various government policies that force people to reduce their activities outside the home, the various necessities of life that have been associated with MSMEs have been reduced. As a consequence, the volume of goods that have been produced by MSMEs has also decreased, which has an impact on their income.

Various government policies during this pandemic also influenced the implementation of social capital in the dynamics of the business world, especially MSMEs. The existence of restrictions on people leaving the house must affect their level of activity which is usually related to their needs for goods produced by MSMEs. The social networks we have so far also cannot function properly. This happens because the government is more concerned with efforts that can be made to hack the spread of covid-19 and maintain public safety [5], [10].

Second, the imposition of layoffs is something that cannot be avoided by MSME actors during the Covid-19 pandemic. The imposition of layoffs is the last option forcibly taken by MSME actors because of their inability to pay employee wages. This reality is relevant if it is studied using James Coleman's rational choice theory [14]. The theory emphasizes that the actor takes an action by utilizing the available resources to achieve a goal. This means that actions taken by actors are actions that are anticipatory to the decrease in the ability of their businesses to pay their employees' salaries. Their decision to lay off their employees, in view of this theory, is a rational choice based on certain reasons to achieve certain goals as well. The existence of this pandemic has caused a decline in demand for production produced by MSMEs which has resulted in a decrease in their income. This decrease in income causes a decrease in the ability of MSMEs to pay their employees' salaries or wages. Thus, to maintain its business activities in order to exist, the option is to reduce the number of employees (see Table V).

Third, changes in the production system are also one of the indicators that have also undergone changes during the Covid19 pandemic. Based on the presentation of the data presented in Table VI, it can be explained that both MSME actors who are members of the UMKM association and those who are not active in an MSME association generally make changes to the production system during the Covid-19 pandemic. This condition is very relevant if analyzed using the theory of rational choice from James Coleman which emphasizes that actors take action by utilizing their resources to achieve a goal [14]. This means that changes in the production system carried out by actors, in this case MSME actors who are members of the UMKM association or who are not joined into an association, are rational actions to take as a strategy to survive this Covid-19 pandemic. It appears somewhat strikingly that MSMEs involved in associations change more in their production systems than those who are not involved in an association. This can explain that social capital in the form of networks created because they are involved in associations has benefited them. By being active in an association, the network they have becomes even wider. Thus their endurance also becomes higher. Changes in the production process or system 
certainly affect the sustainability of their business and increase their income [4]. Activeness in the association causes them to be more intense in communicating, so that various changes in the production process are carried out according to developments that have occurred as a result of this pandemic. The synergy between one UMKM actor and another will also occur. By associating them, they can build networks and with their own networks, MSMEs will grow healthier collectively or collectively.

\section{CONCLUSION}

From the description and analysis above, the following conclusions can be drawn, the existence of the Covid-19 pandemic in West Nusa Tenggara has affected the lives and performance of MSMEs in NTB, including those related to income, layoffs of employees and changes process or production system. In general, the income of MSME players has decreased. Layoffs of employees also occurred. Likewise, related to changes in the production system. Regarding the performance of MSMEs involved in the MSME association compared to those who are not involved in an association, it can be concluded that those who are involved in an association are more dynamic in facing changes in circumstances as a result of a pandemic, compared to MSMEs who are not involved in an association. an association. Those who are involved in an association find it easier to make changes to the production process. This is because the social capital they have is better. They have a business network that allows them to be more adaptive to the changes in the business world that have occurred as a result of the pandemic.

Research during this pandemic does have various limitations, especially in extracting data or information needed to achieve research objectives. However, extracting information online, besides having weaknesses, also has advantages. The advantage is that the respondents who can be reached are wider, when compared to conventional data mining. Regarding the data collection method in this study, it can be suggested to collect as much information from respondents as possible. With a large number of respondents, the data can then be "clean up" meaning that we can reduce respondents who are not representative by leaving the number of respondents who are sufficiently representative for the required calculations and analyzes. Providing assistance to MSMEs is still needed to assist the development of these MSMEs; especially during this pandemic so that they can survive and contribute to the regional economic life. 3 . Encourage MSMEs to be active in UMKM associations so that there is a productive synergy between one UMKM and another. By associating, they will certainly build a network and with the network they have, MSMEs will grow healthier and grow together.

\section{REFERENCES}

[1] A. F. Thaha, "Dampak covid-19 terhadap UMKM di Indonesia," Brand J. Ilm. Manaj. Pemasar., vol. 2, no. 1, pp. 147-153, 2020.

[2] I. Kickbusch, G. M. Leung, Z. A. Bhutta, M. P. Matsoso, C. Ihekweazu, and K. Abbasi, "Covid-19: how a virus is turning the world upside down.” British Medical Journal Publishing Group, 2020.

[3] S. Mulyani, "Menkeu: Dampak Covid-19, Pertumbuhan Ekonomi Indonesia 2020 bisa Minus 0,4 persen,” 2020. https://www.voaindonesia.com/a/menkeu-dampak-covid-19pertumbuhan-ekonomi-indonesia-2020-bisa-minus-0-4persen/5355838.html (accessed May 18, 2021).

[4] D. A. D. Nasution, E. Erlina, and I. Muda, "Dampak Pandemi COVID-19 terhadap Perekonomian Indonesia," J. Benefita, vol. 5, no. 2, p. 212, Jul. 2020, doi: 10.22216/jbe.v5i2.5313.

[5] W. laura Hardilawati, "Strategi Bertahan UMKM di Tengah Pandemi Covid-19," J. Akunt. dan Ekon., vol. 10, no. 1, pp. 8998, 2020

[6] J. A. Dani and Y. Mediantara, "Covid-19 dan Perubahan Komunikasi Sosial," Persepsi Commun. J., vol. 3, no. 1, pp. 94102, 2020.

[7] J. D. Willms, "Student engagement at school: A sense of belonging and participation," OECD Retrieved from www pisa oecd org March, pp. 1-84, 2003, doi: 10.1787/19963777.

[8] "Dampak covid-19 di provinsi NTB_BPS."

[9] S. Khafid, "Gubernur NTB Umumkan Kasus Positif Corona Pertama di Lombok - Nasional Tempo.co," Tempo, Mar. 24, 2020. https://nasional.tempo.co/read/1323462/gubernur-ntb-umumkankasus-positif-corona-pertama-di-lombok (accessed May 18, 2021).

[10] A. Amri, "Dampak covid-19 terhadap UMKM di Indonesia," Brand J. Ilm. Manaj. Pemasar., vol. 2, no. 1, pp. 123-131, 2020.

[11] Sherly, "Provinsi NTB | Gubernur Zul Ajak UMKM terus tingkatkan Kapasitas \& Kualitas Produk," Sep. 07, 2020. https://www.ntbprov.go.id/post/program-unggulan/gubernur-zulajak-umkm-terus-tingkatkan-kapasitas-kualitas-produk (accessed May 18, 2021).

[12] M. I. PRATIWI, "Dampak Covid-19 Terhadap Perlambatan Ekonomi Sektor Umkm,” J. Ners, vol. 4, no. 2, pp. 30-39, 2020.

[13] R. Syahra, "Modal sosial: Konsep dan aplikasi," J. Masy. dan Budaya, vol. 5, no. 1, pp. 1-22, 2003.

[14] G. Ritzer and D. J. Goodman, "Teori Sosiologi Modern, trans," Alimandan. Jakarta Kencana Prenada Media Gr., 2010. 